\title{
Quantifying Cooperation: Collaborative Digital Reference Service in the Large Academic Library
}

\author{
Sandra L. De Groote, Josephine L. Dorsch, \\ Scott Collard, and Carol Scherrer
}

The purpose of this study was to determine how successfully a large academic library with multiple reference departments and subject specialties could combine virtually to create one digital reference service. Questions were coded to determine who the users of the service were, the types of questions being asked, and the subject expertise of the librarian answering the question. The study found that the majority of questions were submitted by persons affiliated with the university, that ready reference and directional questions predominated, and that the librarians were able to successfully share the duty of answering the general reference questions while ensuring that the questions requiring subject expertise were answered by the appropriate subject specialists. Analysis of the types of questions will inform future decisions regarding webpage redesign, online instruction needs, and more appropriate FAQs (frequently asked questions.)

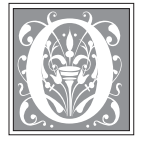

ver the past several years, digital reference has become an integral part of the services offered by academic libraries. The use of networked information systems to deliver asynchronous help to library patrons via e-mail has allowed librarians to reach their users at this new virtual "point of need," and the introduction of chat technology has allowed an even greater level of interactivity by providing real-time, on-demand service.
However, these new capabilities have necessitated a certain amount of adjustment in academic libraries, and the need for this adjustment points up the importance of assessment and evaluation in the planning, implementation, and provision of digital services.

In March 2003, the University of Illinois at Chicago (UIC) library undertook an overhaul and reconfiguration of its public services activities, particularly those services offered online. This proj-

Sandra L. De Groote is an Assistant Information Services Librarian, Library of the Health Sciences, University of Illinois at Chicago; e-mail: sgroote@uic.edu. Josephine L. Dorsch is the Health Sciences Librarian at the Library of the Health Sciences - Peoria, University of Illinois at Chicago; e-mail: jod@uic.edu. Scott A. Collard is Librarian for Psychology, Education, and Linguistics, New York University; e-mail: scott. collard@nyu.edu. Carol Scherrer is the Information Services Librarian, Library of the Health Sciences, University of Illinois at Chicago; e-mail: cscherre@uic.edu. 
ect examined the interrelationships among digital services librarywide, focusing especially on the provision of reference and information services in the digital environment. The task force charged with this examination was instructed to investigate and implement synchronous online reference services (chat reference) for the entire library and to make necessary organizational adjustments to support this new service. Though implementation of a digital reference service option was not extraordinary, the UIC library's situation encompassed a number of specific challenges that quickly became apparent as the project developed. The first and most obvious challenge was that UIC is a highly subject- and geographically dispersed organization, composed of the Daley Library, which serves liberal arts and sciences, visual arts and architecture, and government documents; the Science Library, which serves the physical sciences; and four Health Sciences Libraries (LHS) located in four different cities throughout Illinois (Chicago, Peoria, Rockford, and Urbana), which serve the medical school communities. In implementing the service, the task force would need to consider carefully the impact it would have on diverse patron bodies as well as the staff who would assert primary control over the services. Any solution would need to take into account the different levels of staffing, a diversity of reference styles, and a need for a high degree of flexibility and autonomy in the scheduling and provision of service, in addition to the diversity of subject disciplines and the physical dispersion of the library. The implementation team eventually selected OCLC's QuestionPoint product because it satisfied many of these requirements, particularly in the flexibility it showed in creating self-defined collaborative units, the ability to "move" questions around the system easily and efficiently, and the question-logging capabilities inherent in the product.

\section{Background and Purpose}

The investigation led the task force to conclude that provision of this new service would be best achieved through a significant reorientation of existing reference service. Traditionally, e-mail reference had been provided and handled by the individual reference departments. A Web form was available where the patron would select the library/department expected to answer the question. (See figure 1.) Anecdotal evidence suggested that patrons were not always successful in submitting their questions to the appropriate library or department. Rather than maintain separate and distinct services at UIC's numerous locations, the digital reference management system was introduced to centralize the location where questions were submitted and viewed. This centralized digital reference management system created a shift toward a collaborative, shared digital reference model that would take advantage of staffing and subject expertise available across the library. Further, instead of relying on patrons to determine where their inquiries should be sent, reference librarians would make the selection, thus providing one simple and seamless patron interface to digital reference services at UIC. Lastly, with a single digital reference system, personnel at each library site would be shared more efficiently across all sites.

However, moving from the previous model to this integrated approach would prove difficult because the shift would be made simultaneously for all reference units of the library and would include thirty-five librarians at all library locations. It would be particularly challenging to create a means of assessment that would enable the implementation team to measure the success of the shift and that also would be quantifiable, statistically relevant, and reproducible at future intervals. In essence, the task force wanted to explore whether a single service could replace multiple services that were previously disparate, highly discipline specific, and independently controlled 
by dispersed library departments and sites. Further, the task force wanted to investigate the possibility of measuring the relative success of such a venture by quantifying data inherent in the questions themselves, on the basis of user status, subject area, answering processes, and a host of other criteria. Moreover, this project would measure a multitude of other factors that could be taken into account

\begin{tabular}{|c|}
\hline FIGURE 1 \\
Ask a Reference Question \\
\hline \hline
\end{tabular}

NOTE: all sections are required.

Library/Service Desk Desired (NOTE: Information links will open into a new browser window.)

Architecture \& Art Library| Information

Daley (Main) Library Reference Information

Government Documents Department $\mid \underline{\text { Information }}$

OLibrary of the Health Sciences - Chicago Information

Library of the Health Sciences - Peoria $\underline{\text { Information }}$

OLibrary of the Health Sciences - Rockford Information

OLibrary of the Health Sciences - Urbana $\mid \underline{\text { Information }}$

OMap Section| Information

OScience Library Information

OSpecial Collections \& Univ. Archives | Information

Your name:

Your e-mail address:

Status:

UIC Faculty

UIC Staff

UIC Graduate student

UIC Undergraduate student

UIC Alumna/Alumnus

Not Affiliated with UIC

Question:

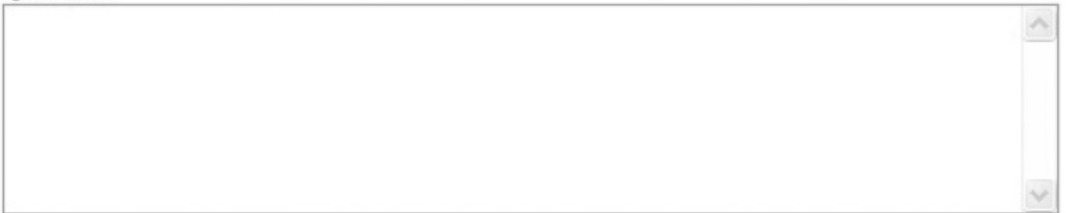

Submit the request 
Quantifying Cooperation 439

\begin{tabular}{|c|c|c|c|c|c|c|c|c|c|c|c|}
\hline & & 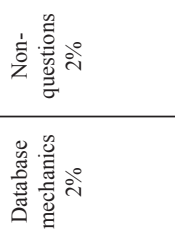 & 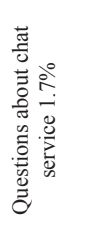 & 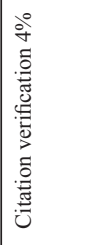 & $\frac{\circ}{i n}$ & 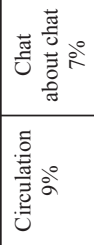 & 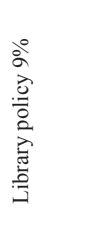 & 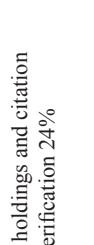 & 总 す & 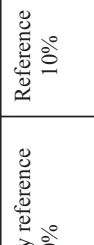 & 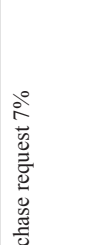 \\
\hline & & 造 i̊ & 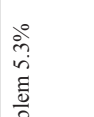 & 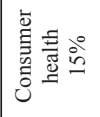 & 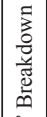 & 总 & $\therefore$ & 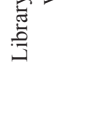 & 胥 & 离 & $\underline{\Xi}$ \\
\hline 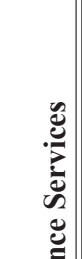 & & 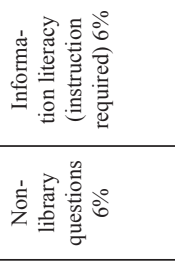 & 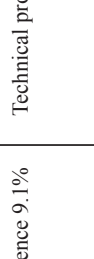 & 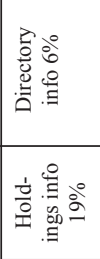 & 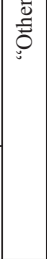 & 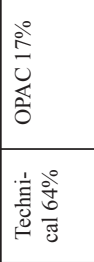 & 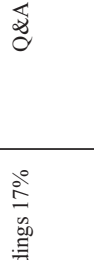 & 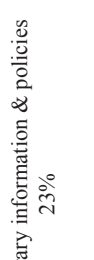 & $\begin{array}{l}80 \\
2 \\
0 \\
0 \\
0 \\
0 \\
0 \\
0 \\
5 \\
4 \\
4\end{array}$ & 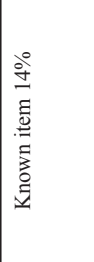 & 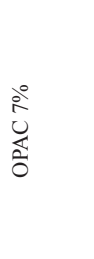 \\
\hline 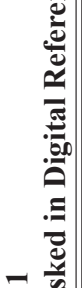 & & 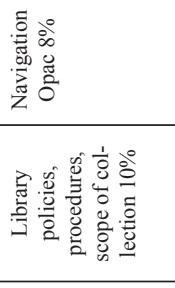 & 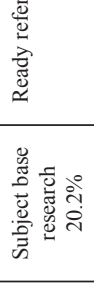 & 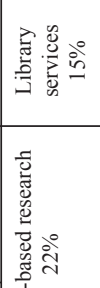 & & 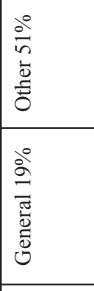 & 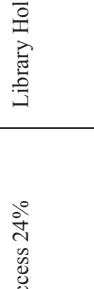 & 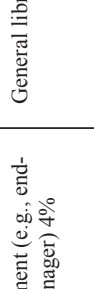 & 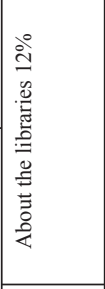 & 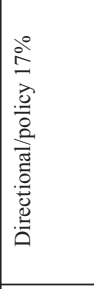 & 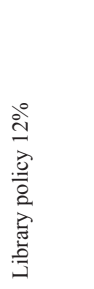 \\
\hline 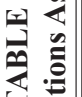 & & 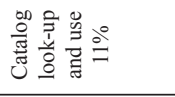 & 声总 & & 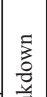 & 素点 & 4 & 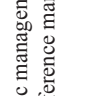 & ฝें & 章 & \\
\hline 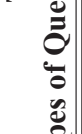 & & 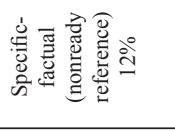 & 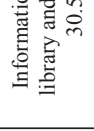 & 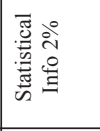 & 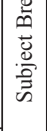 & 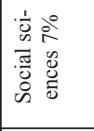 & & 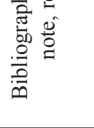 & 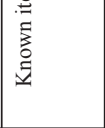 & 嘅 & \\
\hline 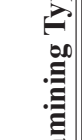 & & 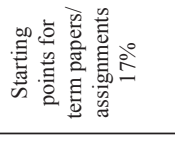 & 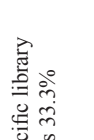 & 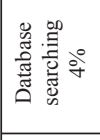 & & 总 & 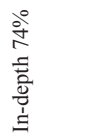 & 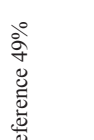 & $\begin{array}{l}\stackrel{2}{\grave{2}} \\
\text { a }\end{array}$ & 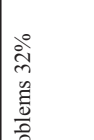 & 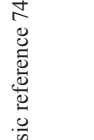 \\
\hline 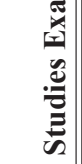 & 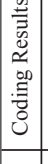 & 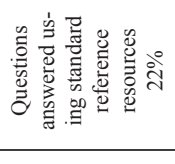 & 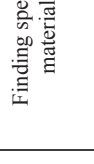 & 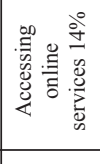 & & 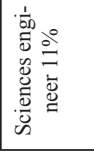 & & 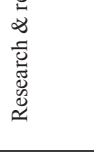 & 总 & 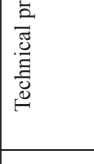 & $\ddot{n}$ \\
\hline & 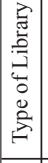 & 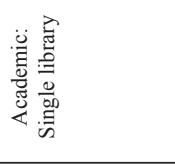 & 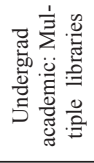 & 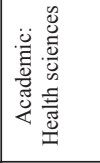 & & 总. & 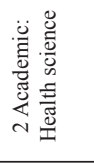 & 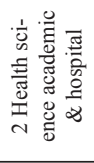 & 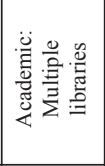 & 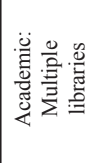 & 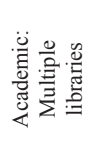 \\
\hline & 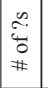 & 字璦 & $\frac{0}{0} \frac{\pi}{0}$ & 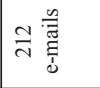 & \begin{tabular}{|l}
$\frac{n}{0}$ \\
$\frac{\tilde{g}}{0}$
\end{tabular} & & $\stackrel{\infty}{n} \frac{n}{\tilde{c}}$ & 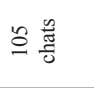 & 氙 & $\begin{array}{l}n \\
\infty \\
\infty\end{array}$ & 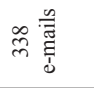 \\
\hline & 音 & $\begin{array}{c}n \\
\stackrel{n}{n} \\
i\end{array}$ & $\simeq \frac{n}{\ddot{0}}$ & $\begin{array}{l}n \\
2 \\
n \\
n \\
n\end{array}$ & & & 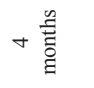 & ○葶 & & 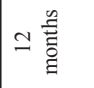 & 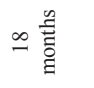 \\
\hline & 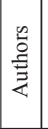 & 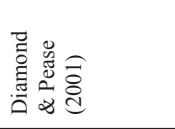 & 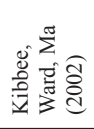 & 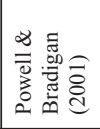 & & 惫 & 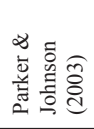 & 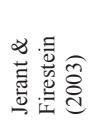 & 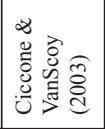 & 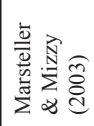 & 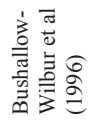 \\
\hline
\end{tabular}


as the service evolved and grew. Some of the areas of inquiry included:

- What types of questions would be submitted to the service and by whom (students, faculty, staff, the public)?

- Would examination of questions provide information or feedback that would allow better service to patrons?

- Would the types of questions submitted through chat differ from the questions submitted through e-mail?

Answers to these and other questions would allow the administrators of the system to fine-tune the functions of the system and steer a future course based on quantified data collected from actual interactions.

This study presents the results of the data gathered and discusses their outcomes and meanings. It also documents the types of questions received through the service, the impact on the role of the reference librarian in the digital environment, and the adequacy of the library's Web services and resources based on frequently asked questions (FAQs).

\section{Literature Review}

The types of questions asked in the online environment are well documented in both the health sciences and social sciences library literature. Coding categories used by the various libraries examining their digital reference questions vary as much as the results of the coding. Some studies provided detailed categories for coding digital questions; others examined the questions more generally. Table 1 provides a summary of several studies examining the types of questions asked in the digital library environment. ${ }^{1-9}$

Several studies documenting the types of questions asked in the digital environment provide data that suggest one virtual reference desk may be a realistic option. For example, all the studies in the literature reviewed included a category dealing with holdings information. (See table 1.) Questions about library holdings ranged from 7 to 33 percent. Questions dealing with library policies also con- stitute a well-documented category in which any librarian, regardless of specific subject expertise, could probably field the question. Questions about library policies, procedures, and services ranged from 9 to 30 percent. The above findings suggest that the subject expertise of the librarian may not necessarily be required in all cases to answer all questions. Therefore, it would be quite likely that librarians of multiple backgrounds could conceivably share the workload at a combined virtual reference desk, leaving the questions requiring subject expertise to be answered by the subject experts.

Wendy Diamond and Barbara G. Pease, noting a lack of detail in the literature about the types of questions that libraries were receiving in the digital environment, developed a detailed coding system to analyze the submitted questions. ${ }^{10}$ Eleven question categories were created to code the types of questions received. (See table 1.) The questions also were examined for complexity: noncomplex (35\%), broad or complex (35\%), standard reference (22\%), and referrals and nonquestions (8\%). Diamond and Pease concluded that digital reference questions cover the full range of simple to complicated questions that are similar to questions asked in-person. ${ }^{11}$ Although this study was one of the first to provide a detailed look at the types of questions asked, it was conducted in a single library.

Carol A. Powell and Paula S. Bradigan also provided an in-depth look at the types of questions submitted in the digital environment to an academic health sciences library. (See table 1. ) $^{12}$ Twenty-two percent of questions asked by faculty, students, or staff were related to information needed for assignments or patient care, which sometimes resulted in searching databases for citations and abstracts. Patrons requesting holdings information accounted for 19 percent of the questions. Requests for information about library services, such as the policies or procedures, accounted for 15 percent of the questions asked. Consumer health 
questions accounted for 15 percent of the questions.

None of the studies in table 1 documented the specifics of questions asked related to holdings information. Was the user asking about a book, a journal, or an online journal? Also lacking in the current literature is a direct comparison between questions asked in chat and questions asked through e-mail reference. Further, it should be noted that although many of the studies reviewed provide a thorough examination of the questions asked in the digital environment, they were predominantly studies about questions submitted to a specific library and not to a central location or where multiple libraries had a shared digital reference service, but the discipline orientation of the libraries was the same.

Although two studies did report on shared chat reference services at universities with multiple libraries, the published findings of the studies did not really gauge the value or success of a shared service to serve multidisciplinary user groups. Josephine Z. Kibbee, David Henry Ward, and Wei Ma, who studied the questions submitted to a shared chat reference service between two different discipline libraries, noted: "Collaboration between two library units in sharing patrons and questions added an additional challenge, but ultimately enabled us to extend hours and service." ${ }^{13}$ Matthew R. Marsteller and Neuhaus also described the types of questions submitted to a shared chat reference service provided by several libraries at one university. ${ }^{14}$ Although the study was not concerned primarily with the results of collaboration among multiple libraries, it was noted that librarians did not always have the needed subject background to answer a question. A system was in place for referring questions to "appropriate libraries on-campus, to library departments (e.g., circulation), and to subject specialist librarians." Also, neither of these shared chat service studies specifically examined

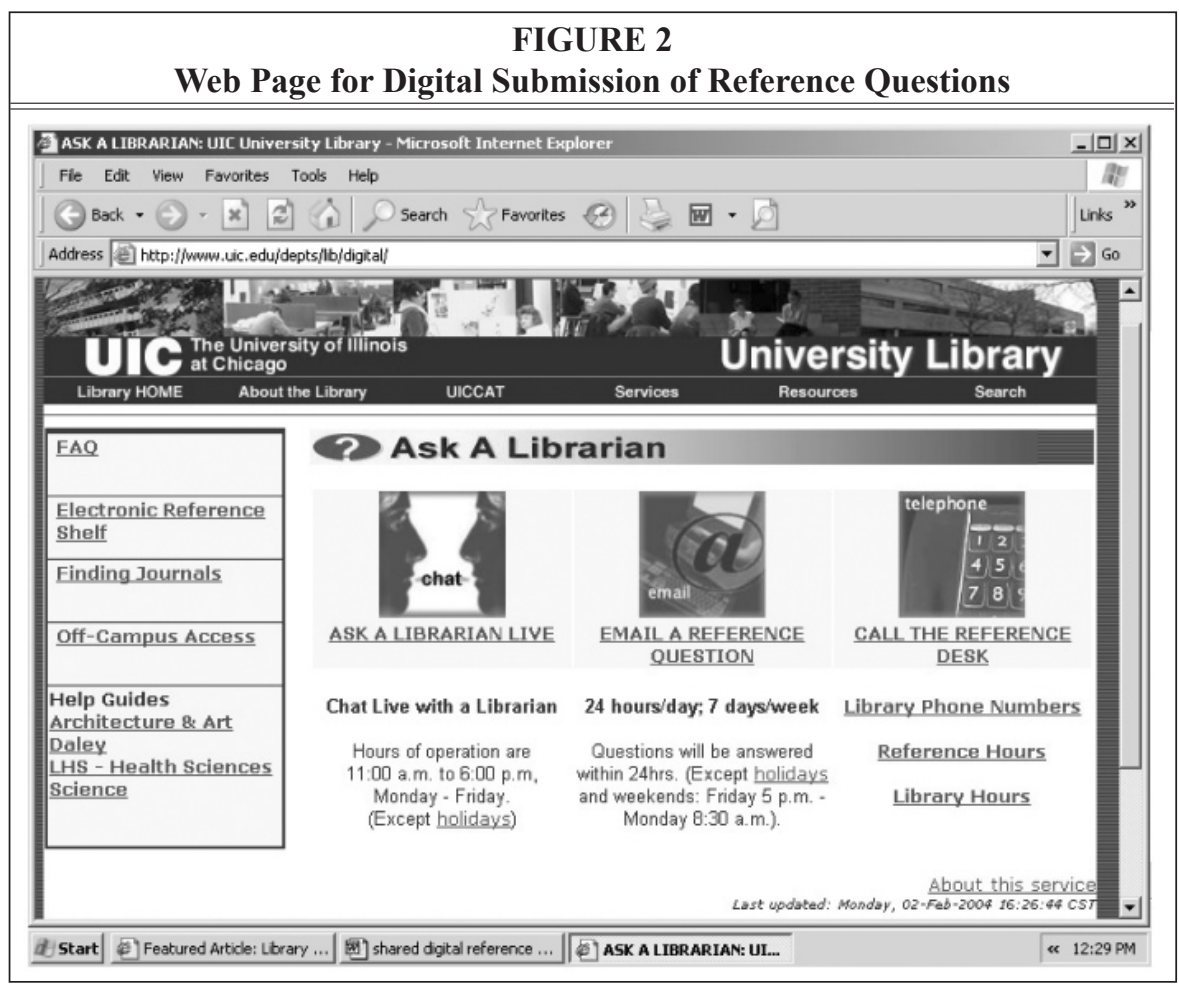


the subject expertise of the librarian answering the question versus the type of question asked or the subject nature of the questions.

\section{Setting}

UIC is a large urban university with three regional medical campuses. Enrollment totals more than 25,000 students with approximately 5,500 enrolled in the health sciences. The existing form for submitting reference questions was removed (figure 1 ), and a Web page was developed for digital submission of reference questions either through e-mail or chat (figure 2). Chat was offered only between the hours of 11 a.m. and 6 p.m., Monday through Friday. No limits were placed on the types of questions that could be asked through the Ask a Librarian service. A link to Ask a Librarian was provided through a template on all library Web pages. Reference departments also provided a link to the Ask a Librarian page from all departmental reference pages. Departments such as circulation, interlibrary loan, special collections, and library systems continued to make the e-mail addresses of these departments available on their Web pages.

Guidelines were developed for the provision of reference services in the digital environment prior to their official introduction. With multiple libraries and library departments sharing one service, it was important that the questions continued to be answered by the librarians most qualified. Therefore, one librarian representing one of the four health sciences reference departments and one librarian representing the Daley library (arts and sciences/government documents) were assigned to do e-mail reference each day. (A librarian from the Science Library was available as backup for Daley reference.) The librarian most qualified would answer the question, and those questions that did not require subject expertise could be answered by either of the librarians on duty. If necessary, questions also could be assigned to the most appropriate librarian or department (e.g., science, special collections) if they were not best answered by one of the librarians on duty. With respect to the chat service, a limited number of available librarians meant that only one librarian at a time would monitor the chat service. Because this would increase the likelihood that librarians might encounter a question outside their subject expertise, guidelines were developed to encourage librarians to answer the question as best they could in such instances and to assign the chat transcript to the appropriate subject expert(s) for follow-up via e-mail.

\section{Methodology}

A coding system was developed through examining a range of sources. Other studies that had coded reference transactions in both the traditional and digital environments were examined to develop a basis for the coding system. ${ }^{15-24}$ In addition, questions asked of the UIC reference departments were examined to fill in any gaps related to typically asked questions and subject areas. The coding system that was subsequently developed was tested using questions submitted to the digital reference service in June and July 2003, prior to the official sampling and coding of the questions. Problems and omissions were noted, and the coding system was adjusted as appropriate. The researchers also used the time to train themselves to use the coding system. Inter-rater reliability testing was done to ensure that all researchers were defining and coding the information accurately. An inter-rater reliability of 82 percent was achieved among the four coders before the official data collection began.

From August 1, 2003, to March 31, 2004, random samplings of 120 questions submitted (either chat or e-mail) per month to the Ask a Librarian service were examined. The sampling of the questions was determined by using random number generator software. Coded information was entered into a spreadsheet to determine frequency. (See 


\begin{tabular}{|c|c|c|c|c|c|c|c|c|c|c|c|c|c|}
\hline \multicolumn{14}{|c|}{$\begin{array}{c}\text { TABLE } 2 \\
\text { Total Questions Asked of the Ask a Librarian Service, } \\
\text { April } 2003 \text { to March } 2004\end{array}$} \\
\hline & \begin{tabular}{|c|} 
April \\
'03
\end{tabular} & $\begin{array}{c}\text { May } \\
\text { '03 }\end{array}$ & $\begin{array}{c}\text { June } \\
\text { '03 }\end{array}$ & $\begin{array}{c}\text { July } \\
{ }^{\prime} 03\end{array}$ & $\begin{array}{c}\text { Aug } \\
\text { '03 }\end{array}$ & $\begin{array}{c}\text { Sept } \\
\text { '03 }\end{array}$ & $\begin{array}{l}\text { Oct } \\
\text { '03 }\end{array}$ & $\begin{array}{c}\text { Nov } \\
\text { '03 }\end{array}$ & $\begin{array}{c}\text { Dec } \\
{ }^{\prime} \mathbf{0 3}\end{array}$ & $\begin{array}{l}\text { Jan } \\
\text { '04 }\end{array}$ & $\begin{array}{l}\text { Feb } \\
\text { '04 }\end{array}$ & $\begin{array}{c}\text { Mar } \\
\text { '04 }\end{array}$ & Total \\
\hline Chat & 98 & 31 & 43 & 43 & 50 & 112 & 113 & 79 & 64 & 102 & 107 & 152 & 994 \\
\hline E-mail & 119 & 68 & 98 & 80 & 103 & 163 & 122 & 102 & 43 & 106 & 139 & 148 & 1,291 \\
\hline Global Q & 5 & 2 & 4 & 2 & 1 & 0 & 0 & 0 & 0 & 0 & 1 & 0 & 15 \\
\hline Total & 222 & 101 & 145 & 125 & 154 & 275 & 235 & 181 & 107 & 208 & 247 & 300 & 2,300 \\
\hline
\end{tabular}

the appendix.) General coding categories included month, subject area, user status, how the question was submitted, what department answered the question, the type of question submitted, and how the question was answered.

\section{Results}

Table 2 provides the number of questions submitted to the Ask a Librarian service from April 2003 to March 2004. Questions were coded from August until March 2004. Because December 2003 only had 107, all 107 questions were coded.

In total, 932 questions were coded. The status of the users of the service and the way in which questions were submitted are presented in table 3 . UIC affiliates were the largest users of the digital reference service $(63 \%)$, composed of graduate students $(23.7 \%)$, undergraduates $(23 \%)$, and faculty $(15.9 \%)$. Visitors accounted for 28 percent of the questions submitted.
In 5.9 percent of the questions asked, it was not possible to determine the status of the user because his or her status was not provided and/or he or she did not provide a UIC e-mail address. Some questions (3.6\%) were coded as "aborted" because a patron appeared, but a question was not asked. Aborted chats were due to technical problems, people asking the same question consecutively while they already had a chat session open, and the curious. E-mail was used more frequently for submitting questions. Faculty (77.1\%), graduates students $(62.2 \%)$, and visitors (71.7\%) were most likely to use e-mail; undergraduates were most likely to use chat $(66.5 \%)$.

Figure 3 presents the general categories for the types of questions asked and the user group asking them. Ready reference questions (those that required only quick interactions, for example, known-item searches) were the most

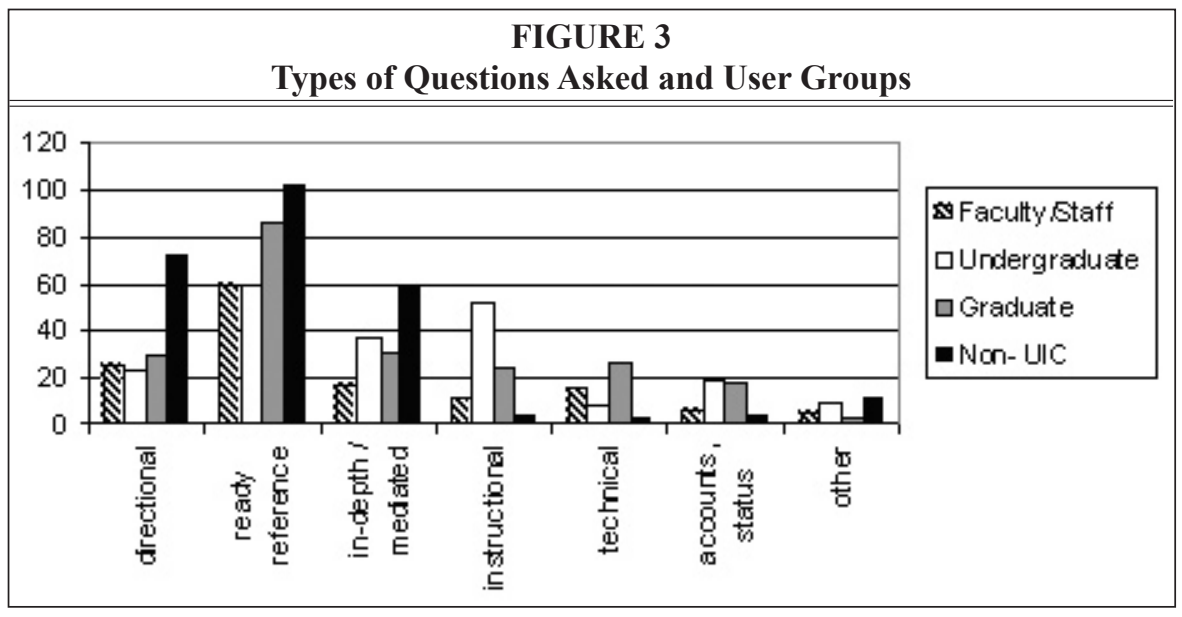


frequent, accounting for 37 percent of the questions. Other large categories were in-depth/mediated questions (17.9\%), directional questions (17.5\%), and questions in which either the patron directly requested instruction or the librarian deemed it necessary to instruct the patron in the use of resource(s) $(11.8 \%)$. All groups asked a large number of ready reference questions (faculty, $42.1 \%$; graduate students, $39.3 \%$; undergraduates, $28.4 \%$; visitors, $39.7 \%$ ). Undergraduates were responsible for 25 percent of the instructional questions submitted, and visitors asked 28 percent of the directional questions.

\begin{tabular}{|c|c|c|c|c|}
\hline \multicolumn{5}{|c|}{$\begin{array}{c}\text { TABLE } 3 \\
\text { User Status vs. How Submitted }\end{array}$} \\
\hline \multirow{2}{*}{\multicolumn{2}{|c|}{ User Status }} & \multicolumn{2}{|c|}{$\begin{array}{c}\text { How Question } \\
\text { Was Submitted }\end{array}$} & \multirow{2}{*}{$\begin{array}{c}\text { Total Questions } \\
\text { Asked by User } \\
\text { Group }\end{array}$} \\
\hline & & E-mail & Chat & \\
\hline \multirow[t]{4}{*}{ Faculty/ Staff } & Count & 108 & 32 & 140 \\
\hline & $\%$ within user status & $77.1 \%$ & $22.9 \%$ & $100.0 \%$ \\
\hline & $\%$ within how submitted & $22.1 \%$ & $8.1 \%$ & $15.9 \%$ \\
\hline & $\%$ of total & $12.2 \%$ & $3.6 \%$ & $15.9 \%$ \\
\hline \multirow{4}{*}{$\begin{array}{l}\text { Undergraduate } \\
\text { Students }\end{array}$} & Count & 68 & 135 & 203 \\
\hline & $\%$ within user status & $33.5 \%$ & $66.5 \%$ & $100.0 \%$ \\
\hline & $\%$ within how submitted & $13.9 \%$ & $34.2 \%$ & $23.0 \%$ \\
\hline & $\%$ of total & $7.7 \%$ & $15.3 \%$ & $23.0 \%$ \\
\hline \multirow{4}{*}{$\begin{array}{l}\text { Graduate } \\
\text { Students }\end{array}$} & Count & 130 & 79 & 209 \\
\hline & $\%$ within user status & $62.2 \%$ & $37.8 \%$ & $100.0 \%$ \\
\hline & $\%$ within how submitted & $26.6 \%$ & $20.0 \%$ & $23.7 \%$ \\
\hline & $\%$ of total & $14.7 \%$ & $8.9 \%$ & $23.7 \%$ \\
\hline \multirow[t]{4}{*}{ Non-UIC } & Count & 177 & 70 & 247 \\
\hline & $\%$ within user status & $71.7 \%$ & $28.3 \%$ & $100.0 \%$ \\
\hline & $\%$ within how submitted & $36.3 \%$ & $17.7 \%$ & $28.0 \%$ \\
\hline & $\%$ of total & $20.0 \%$ & $7.9 \%$ & $28.0 \%$ \\
\hline \multirow[t]{4}{*}{ Unknown User } & Count & 4 & 48 & 52 \\
\hline & $\%$ within user status & $7.7 \%$ & $92.3 \%$ & $100.0 \%$ \\
\hline & $\%$ within how submitted & $.8 \%$ & $12.2 \%$ & $5.9 \%$ \\
\hline & $\%$ of total & $.5 \%$ & $5.4 \%$ & $5.9 \%$ \\
\hline \multirow[t]{4}{*}{ Aborted } & Count & 1 & 31 & 32 \\
\hline & $\%$ within user status & $3.1 \%$ & $96.9 \%$ & $100.0 \%$ \\
\hline & $\%$ within how submitted & $.2 \%$ & $7.8 \%$ & $3.6 \%$ \\
\hline & $\%$ of total & $.1 \%$ & $3.5 \%$ & $3.6 \%$ \\
\hline \multirow[t]{4}{*}{ Total } & Count & 488 & 395 & 883 \\
\hline & $\%$ within user status & $55.3 \%$ & $44.7 \%$ & $100 \%$ \\
\hline & $\%$ within how submitted & $100 \%$ & $100 \%$ & $100 \%$ \\
\hline & $\%$ of total & $55.3 \%$ & $44.7 \%$ & $100 \%$ \\
\hline
\end{tabular}




\begin{tabular}{|c|c|c|c|c|}
\hline \multicolumn{5}{|c|}{$\begin{array}{c}\text { TABLE } 4 \\
\text { Question Asked versus How Submitted }\end{array}$} \\
\hline \multirow{2}{*}{\multicolumn{2}{|c|}{ Question Asked }} & \multicolumn{2}{|c|}{$\begin{array}{c}\text { How a Question } \\
\text { was Submitted } \\
\text { within Question } \\
\text { Asked }\end{array}$} & \multirow{3}{*}{$\begin{array}{c}\begin{array}{c}\text { Total } \\
\text { of Each } \\
\text { Question } \\
\text { Asked }\end{array} \\
80\end{array}$} \\
\hline & & E-mail & Chat & \\
\hline \multirow[t]{2}{*}{ Looking for articles on topic $\mathrm{X}$} & Count & 33 & 47 & \\
\hline & within question (\%) & 41.3 & 58.8 & 9.4 \\
\hline \multirow[t]{2}{*}{ Research consultation } & Count & 7 & 1 & 8 \\
\hline & within question (\%) & 87.5 & 12.5 & .9 \\
\hline \multirow[t]{2}{*}{ Location of information on topic $\mathrm{X}$} & Count & 74 & 46 & 120 \\
\hline & within question (\%) & 61.7 & 38.3 & 14.1 \\
\hline \multirow[t]{2}{*}{ Database mechanics } & Count & 10 & 11 & 21 \\
\hline & within question (\%) & 47.6 & 52.4 & 2.5 \\
\hline \multirow[t]{2}{*}{ Accessing e-resources } & Count & 19 & 12 & 31 \\
\hline & within question (\%) & 61.3 & 38.7 & 3.6 \\
\hline \multirow[t]{2}{*}{ Accessing e-journals } & Count & 37 & 15 & 52 \\
\hline & within question (\%) & 71.2 & 28.8 & 6.1 \\
\hline \multirow[t]{2}{*}{ Book holdings } & Count & 41 & 40 & 81 \\
\hline & within question (\%) & 50.6 & 49.4 & 9.5 \\
\hline \multirow[t]{2}{*}{ Journal holdings } & Count & 35 & 34 & 69 \\
\hline & within question (\%) & 50.7 & 49.3 & 8.1 \\
\hline \multirow[t]{2}{*}{ AV, special collections holdings } & Count & 51 & 17 & 68 \\
\hline & within question (\%) & 75.0 & 25.0 & 8.0 \\
\hline \multirow[t]{2}{*}{ Factual } & Count & 15 & 17 & 32 \\
\hline & within question (\%) & 46.9 & 53.1 & 3.8 \\
\hline \multirow[t]{2}{*}{ Statistical } & Count & 6 & 4 & 10 \\
\hline & within question (\%) & 60.0 & 40.0 & 1.2 \\
\hline \multirow[t]{2}{*}{ Technical access } & Count & 20 & 17 & 37 \\
\hline & within question (\%) & 54.1 & 45.9 & 4.3 \\
\hline \multirow[t]{2}{*}{ Library hours, location } & Count & 9 & 10 & 19 \\
\hline & within question (\%) & 47.4 & 52.6 & 2.2 \\
\hline \multirow[t]{2}{*}{ Online catalog, My Account } & Count & 17 & 10 & 27 \\
\hline & within question (\%) & 63.0 & 37.0 & 3.2 \\
\hline \multirow[t]{2}{*}{ Library policies and services } & Count & 76 & 54 & 130 \\
\hline & within question (\%) & 58.5 & 41.5 & 15.3 \\
\hline \multirow[t]{2}{*}{ Citation verification } & Count & 1 & 3 & 4 \\
\hline & within question (\%) & 25.0 & 75.0 & .5 \\
\hline \multirow[t]{2}{*}{ Collection suggestions } & Count & 6 & 0 & 6 \\
\hline & within question (\%) & 100.0 & .0 & .7 \\
\hline
\end{tabular}




\begin{tabular}{|c|c|c|c|c|}
\hline \multicolumn{5}{|c|}{$\begin{array}{c}\text { TABLE } 4 \\
\text { Question Asked versus How Submitted }\end{array}$} \\
\hline \multirow{2}{*}{\multicolumn{2}{|c|}{ Question Asked }} & \multicolumn{2}{|c|}{$\begin{array}{c}\text { How a Question } \\
\text { was Submitted } \\
\text { within Question } \\
\text { Asked }\end{array}$} & \multirow{2}{*}{$\begin{array}{c}\text { Total } \\
\text { of Each } \\
\text { Question } \\
\text { Asked }\end{array}$} \\
\hline & & E-mail & Chat & \\
\hline \multirow[t]{2}{*}{ Notice of errors on Web Pages } & Count & 0 & 1 & 1 \\
\hline & within question $(\%)$ & .0 & 100.0 & .1 \\
\hline \multirow[t]{2}{*}{ Complaints, courtesies } & Count & 4 & 2 & 6 \\
\hline & within question (\%) & 66.7 & 33.3 & .7 \\
\hline \multirow[t]{2}{*}{ Other } & Count & 26 & 23 & 49 \\
\hline & within question $(\%)$ & 53.1 & 46.9 & 5.8 \\
\hline \multirow[t]{2}{*}{ Total } & Count & 487 & 364 & 851 \\
\hline & within question $(\%)$ & 57.2 & 42.8 & 100.0 \\
\hline
\end{tabular}

To provide more detailed information about types of questions beyond general categories such as directional, ready reference, and in-depth reference, a more exhaustive list of specific types of questions also was coded. Table 4 presents the number of times specific types of questions were asked and how questions were submitted. Questions related to library services and policies represented the largest group of questions asked (15.3\%). Where would information on a particular topic be found (14.1\%) and looking for articles on a particular topic $(9.4 \%)$ also represented a large number of questions asked. Other popular types of questions included:

- Do you have this book $(9.5 \%)$ ?

- Do you have this journal (8.1\%)?

- Do you have this audiovisual or special material $(8 \%)$ ?

Total questions about materials owned by the library represented about 25.6 percent of the questions.

Users appeared to favor one type of medium over another (e-mail versus chat) for asking specific types of questions. For example, users tended to use e-mail in categories such as research consultation, where to find information on a particular topic, accessing electronic resources (databases and journals), audiovisual hold- ings, statistical information, the library catalog, library services and policies, and suggestions for the collection. Users tended to use chat to ask questions related to finding articles on a particular topic and citation verification.

Table 5 presents the number of times a specific type of question was asked by user status. Faculty/staff were most likely to ask questions related to accessing ejournals $(13.38 \%)$ and questions about library services and policies (15.45\%). Of all the users of the service, undergraduate students were most likely to ask questions related to finding articles on a particular topic $(18.9 \%)$ and asking for a general starting point on where to find information on a particular topic (18.5\%). Graduate students most frequently asked questions related to journal holdings (14\%) and library services and policies $(15.4 \%)$. Visitors (non-UIC) were most likely to ask where information could be found on a general topic $(17.4 \%)$, holdings related to audiovisuals and special collections $(13.9 \%)$, and questions about library services and policies (19.7\%). Each question was examined independently to determine the specific user group most likely to ask each type of question. For example, undergraduate students asked questions related to finding articles on a particular 
topic 48.1 percent of the time, whereas graduate students most frequently asked questions related to database mechanics $(57.1 \%)$, accessing e-journals $(41.5 \%)$, journal holdings information (43\%), technical and access questions (43.3\%), and UICCAT My Account questions (40.64\%). Fifty percent of research consultation requests were from faculty. Visitors were the most likely group to ask questions related to general information $(36.2 \%)$, book-holdings information $(31.7 \%)$, audiovisual and special collections (51.4\%), factual information (60\%), hours and location (68.4\%), and library policies and services (38\%).

Figure 4 presents the number of questions answered by each department and also the subject area of questions asked.
The majority of questions asked were related to the liberal arts (32\%), followed by the health sciences (23.5\%). Science questions accounted for 5.5 percent and government document-related questions for 3 percent. A large number of questions asked were related to library services and/or policies $(21.6 \%)$. The Daley reference department answered the majority of questions (45\%), followed by the health sciences reference department (39.5\%). Forty-four percent of all the questions answered by the health sciences reference librarians were related to the health sciences. Of all the health sciences questions asked, approximately 74 percent were answered by a health sciences librarian. Forty-three percent of the questions answered by the Daley

\begin{tabular}{|c|c|c|c|c|c|}
\hline \multicolumn{6}{|c|}{$\begin{array}{c}\text { TABLE } 5 \\
\text { Type of Question Asked by User Status }\end{array}$} \\
\hline & $\begin{array}{l}\text { Faculty/ } \\
\text { Staff }\end{array}$ & $\begin{array}{l}\text { Under- } \\
\text { graduate } \\
\text { Student }\end{array}$ & $\begin{array}{c}\text { Graduate } \\
\text { Student }\end{array}$ & $\begin{array}{l}\text { Non-UIC } \\
\text { User }\end{array}$ & $\begin{array}{l}\text { Unknown } \\
\text { User }\end{array}$ \\
\hline Looking for articles on topic $\mathrm{X}$ & 4 & 39 & 16 & 12 & 10 \\
\hline Research consultation & 4 & 1 & 2 & 1 & 0 \\
\hline Location of info on topic $\mathrm{X}$ & 10 & 38 & 19 & 45 & 10 \\
\hline Database mechanics & 2 & 7 & 12 & 0 & 0 \\
\hline Accessing e-resources & 9 & 8 & 10 & 4 & 1 \\
\hline Accessing e-journals & 19 & 8 & 22 & 3 & 1 \\
\hline Book holdings & 14 & 16 & 21 & 27 & 7 \\
\hline Journal holdings & 8 & 20 & 31 & 9 & 4 \\
\hline $\mathrm{AV}$, special collections & 11 & 7 & 11 & 36 & 5 \\
\hline Factual & 6 & 5 & 1 & 21 & 2 \\
\hline Statistical & 2 & 6 & 1 & 1 & 0 \\
\hline Technical access & 11 & 5 & 16 & 2 & 3 \\
\hline Library hours, location & 1 & 3 & 2 & 13 & 0 \\
\hline Online catalog, My Account & 5 & 7 & 11 & 2 & 2 \\
\hline Library policies and services & 22 & 23 & 34 & 51 & 4 \\
\hline Citation verification & 2 & 1 & 0 & 2 & 0 \\
\hline Collection suggestions & 1 & 0 & 0 & 6 & 0 \\
\hline Notice of errors on WebPages & 0 & 0 & 0 & 1 & 0 \\
\hline Complaints, courtesies & 3 & 0 & 0 & 3 & 1 \\
\hline Other & 8 & 12 & 11 & 19 & 1 \\
\hline
\end{tabular}




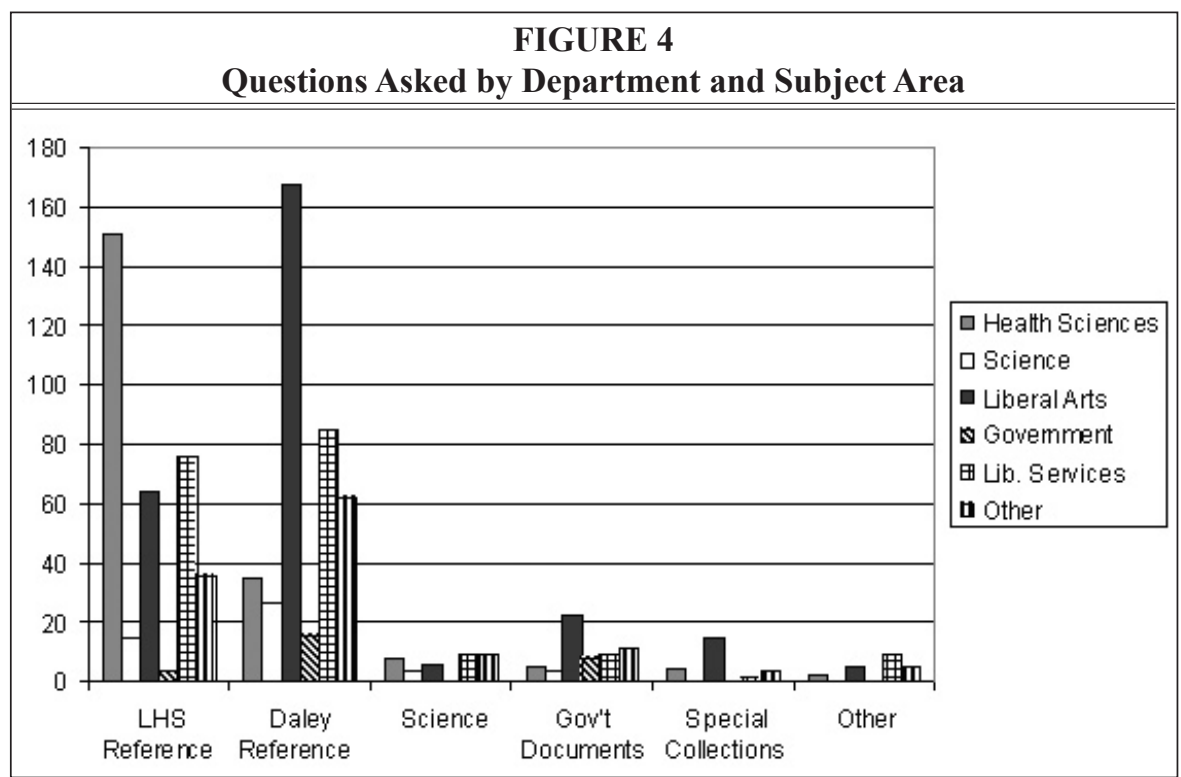

reference department were related to the liberal arts and sciences. Of all the liberal arts and sciences questions asked, 60 percent were answered by the Daley reference librarians. The Daley reference department also answered 56.5 percent of all science questions. Both reference departments contributed relatively equally to answering questions related to library policies and services.

The percentages of questions answered by the respective reference departments in both chat and e-mail also were examined. For e-mail, the health sciences reference department answered most of the health sciences questions (81.1\%) and the social sciences and humanities reference department answered most of the social sciences and humanities questions $(62.4 \%)$. The same pattern held true for chat, although the percentage was not as great when compared with e-mail. The health sciences reference department answered the majority of health sciences questions (64\%) and the social sciences and humanities reference department answered the majority of social sciences and humanities questions (57.3\%).

Figure 5 details the number of times specific questions were asked by various subject disciplines. Questions asked with a health sciences subject were most often related to finding articles on a particular topic $(17 \%)$ or journal-holdings information $(19 \%)$. The most frequent type of question asked in the liberal arts was related to pointing to a general area to find information on a topic $(21.4 \%)$. In the sciences, the most common types of questions were related to journal-holdings information $(20.8 \%)$.

\section{Discussion}

This study examined the effectiveness of a one-service-point digital reference service in a complex academic library composed of multidisciplinary and geographically dispersed libraries. Second, the study sought to measure the relative success of this approach by quantifying data about the questions received, such as user status, subject area, and the answering process.

The fear that the service would be inundated by inappropriate questions from within and outside the university proved unfounded. Use, predictably, followed the academic calendar year with the highest use at the beginning of semesters and the lowest use during winter and summer 


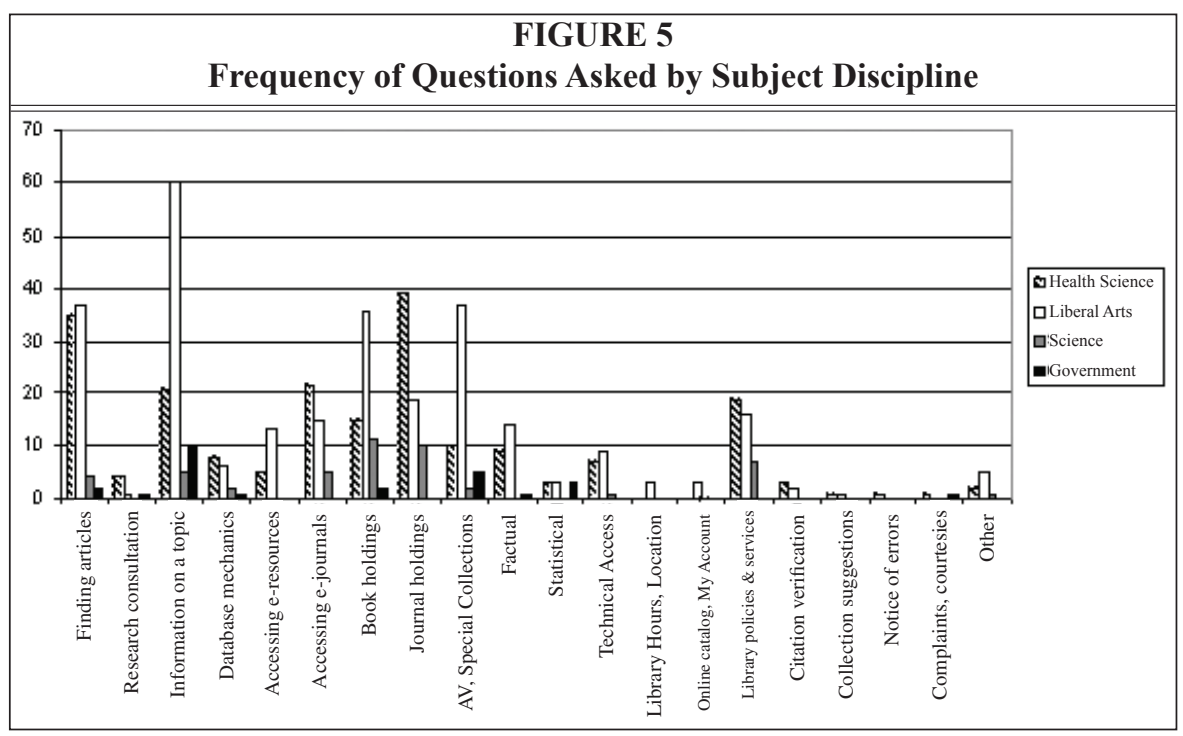

holiday months, possibly indicating the need to reconsider staffing patterns for the Ask a Librarian service. UIC affiliates accounted for nearly two-thirds of the activity. Surprisingly, no questions were referred outside UIC, even though QuestionPoint provided that capability.

Examination of the types of questions asked and how they were submitted provides insight into user preferences and information needs. E-mail was used most frequently for submitting questions. The breakdown within user groups shows that faculty used e-mail 77.1 percent of the time, visitors 71.7 percent of the time, and graduate students 62.2 percent of the time. Perhaps not surprisingly, undergraduates showed a clear preference for chat, submitting 66.5 percent of their questions via this method.

Preference for chat among undergraduates might be attributed to a generational culture attuned to mobile communication and instant messaging. But the preference also may correlate with the information needs of undergraduates as reflected by the types of questions they asked. Analysis of questions showed that queries received via chat tended to relate to how to find articles on a particular topic, the type of question most often asked by undergraduates in this study. This group of users also required the most guidance in selecting databases and pathways for finding information on specific topics. Based on these data, undergraduates not only require intervention in their research activities, but also tend to desire immediate assistance in completing their research tasks. This contrasts significantly with faculty and graduate students, who asked more ready reference and technical questions related to accessing electronic journals than any other user group including undergraduates. Interestingly, a combination of technological comfort and perceived time constraints seems to influence the chosen mode and content of submissions.

Quantifying user communication preferences and types of questions asked by different groups of users informs reference and instructional programs. Obviously, these findings indicate that undergraduates need significant information literacy instruction, but the fact that they combine this need with a sense of urgency suggests that they may be receptive to "on-demand" methods of instruction such as online tutorials and context-sensitive help. Faculty and graduate student questions reflect higher infor- 
mation literacy and less need for guidance in the selection and use of resources. For these more independent users, design changes and improved organization of library Web pages should meet their needs. Indeed, the large number of holdings and policy questions, from all users, point to this need as well. Frequently asked questions by visitors about library services identified a need to develop an FAQ page about library services for alumni and nonaffiliated users. Perhaps future undertakings that focus on increasing usability of library pages should take these findings into account and design methodologies that measure the differences in the ways these user groups interact with the pages.

The majority of visitor queries were, appropriately, specific to UIC library holdings and services. Over a quarter of all queries were for holdings information and 15 percent related to library policies or services. This has several implications. First, given that 41 percent of all queries received required no subject expertise on the part of the librarians, it affirms that a one-stop digital reference service may be an efficient way to provide service, especially considering that when subject expertise was required, questions were generally assigned appropriately. Second, it suggests that reference collaboration across several institutions may not be feasible because 41 percent of questions were UIC-centric. Eventual shared reference with other like institutions had been envisioned and indeed, was one of the primary reasons QuestionPoint was selected over other systems. These findings corroborate similar findings by other investigators that between 19 and 66 percent of questions were related to known item searches or library policies or services. (See table 1.) Kibbee, Ward, and Ma noted that the significant quantity of questions relating specifically to their institution's library resources and services led them to question their ability to share a collaborative digital reference service with another institution. ${ }^{25}$ Although the results here suggest a similar finding, they also argue persuasively that intrainstitutional collaboration in the service is indeed efficient, effective, and desirable.

An analysis of the subject area/types of questions received showed some surprising patterns. Although subject-related questions predominated, 22 percent of questions pertained to library services. It is unlikely that librarians were answering as many of these questions before the implementation of this easily accessible digital reference service. The need to include staff from circulation and interlibrary loan became apparent as this pattern emerged.

The greatest number of questions in the subject breakdown came from the liberal arts $(32 \%)$, followed by the health sciences $(23.5 \%)$. It is noteworthy that such a large percentage came from the health sciences because health sciences students comprise only one-fifth of the student body. This finding may not be all that surprising given that one study found the ratio of remote users to in-house users of academic health science libraries is five to one, compared to 1.3 remote users for each in-house user at "main" academic libraries. ${ }^{26}$

Differences between the types of questions asked by the two main subject groups (health sciences, liberal arts) do reflect discrepancies in their needs. Not surprisingly, the reliance of the health sciences users on journal materials comes through. Of questions about journal holdings, 54.2 percent came from the health sciences and 42.3 percent of the questions about e-journals came from this same group. Other areas in which the health sciences predominated were research consultation and database mechanics, asking 57.1 and 38 percent of the questions in these categories respectively. The need for a wider variety of materials was apparent for the liberal arts users. These users were more likely to ask broader questions on where to seek information on a topic (50\% of questions in this category). This group also asked the greatest percent- 
age of questions (39.4\%) about accessing e-resources (that is, electronic databases and online textbooks), as opposed to ejournals. The preference for monographic information is seen again with this group whose members asked 42.4 percent of the book-holdings questions and 52.9 percent of the questions on audiovisual holdings and special collections.

In total, 9.4 percent of questions were answered through reassignment, referral, or consultation. Although the librarian makes a choice to answer an e-mail question based on its content, he or she does not have a choice with chat, at least not upon initial contact. Despite this, chats occurred often when the subject expert was available. Surprisingly, more questions asked through e-mail were referred to another librarian or answered in consultation with another librarian (9.1\%) than those through chat $(8.6 \%)$. The data show that the department with the relevant subject knowledge answered the majority of questions requiring subject expertise. The one-service-point model used by UIC demonstrates that subject specialists are not underutilized-and perhaps are utilized more effectively -in a dispersed library environment. Anecdotal evidence from librarians implies that working within this model has given them a better understanding of information issues across the university and a deeper appreciation of the specialized skills of their colleagues from other departments and library sites. The authors are investigating the librarians' comfort with, and attitudes toward, a shared digital reference service; results will be reported separately.

\section{Conclusions}

Results of this study demonstrate that a centralized digital reference service is feasible even in a complex academic environment serving a diverse user population with widely divergent disciplines spread across five campuses. Having one contact point relieves the burden of choice for library users looking for real-time and expedient assistance and places the decision with the librarian, who is best equipped to triage the request to the most appropriate person. The success of the service has led to expansion beyond the reference departments to include special collections, circulation, interlibrary loan, and systems. This will mean new challenges in accommodating the range of working patterns and styles across these units. For staffing, it means personnel at each library site will more efficiently be shared across all sites. For users, it means a simple and seamless interface to digital services.

Analysis of the questions asked, how they were asked, and by whom has provided insight into ways the library can improve service to its patrons. A redesigned Web page could provide prominent links to information commonly requested, such as library privileges for alumni or pathways to specific subject resources grouped by user status. The need for instructional programs, both online and in the classroom, could be identified and developed to address those areas that generate the most confusion and frustration for patrons. A compilation of FAQs or context-sensitive help screens could be assembled and made easily available to users.

Though questions about the quality of digital reference services remain to be answered, the rich data provided by question logs present us with a chance to evaluate the accuracy and completeness of the service we give our patrons. As a complement to user surveys, chat and e-mail transcripts can offer another measure of user satisfaction. Unlike the fleeting moment of in-person or telephone reference encounters, these methods provide a record that can be analyzed to establish benchmarks for reference service that have heretofore proved elusive. The analysis of submitted questions gives librarians one more channel of information to utilize in decisions about library and Web page usability, instruction activities, and reference services. But more important, it 
provides opportunities for librarians to be proactive in fulfilling our users' needs, removing stumbling blocks that so often impede their progress, and providing better and more valuable access to library resources and services.

\section{Notes}

1. Lara Bushallow-Wilbur, Gemma S. DeVinney, and Fritz Whitcomb, “Electronic Mail Reference Service," RQ 35 (spring 1996): 359-63+.

2. Wendy Diamond and Barbara G. Pease, "Digital Reference: A Case Study of Question Types in an Academic Library," Reference Services Review 29, no. 3 (2001): 210-18.

3. Lisa Lott Jerant and Kenneth Firestein, "Not Virtual, But a Real, Live, Online, Interactive Reference Service," Medical Reference Services Quarterly 22 (summer 2003): 57-68.

4. Karen Ciccone and Amy VanScoy, "Managing an Established Virtual Reference Service," Internet Reference Services Quarterly 8, no. 1/2 (2003): 95-105.

5. Matthew R Marsteller and Danianne Mizzy, "Exploring the Synchronous Digital Reference Interaction for Query types, Question Negotiation, and Patron Response," Internet Reference Services Quarterly 8, no. 1/2 (2003): 149-65.

6. Sandi K Parker and E. Diane Johnson, "The Region 4 Collaborative Virtual Reference Project," Medical Reference Services Quarterly 22 (summer 2003): 29-39.

7. Carol A. Powell and Pamela S. Bradigan, "E-mail Reference Services: Characteristics and Effects on Overall Reference Services at an Academic Health Sciences Library," Reference \& User Services Quarterly 41 (winter 2001): 170-78.

8. Matthew R Marsteller and P. Neuhaus, "The Chat Reference Experience at Carnegie Mellon University," (June 2001). Available online at http://www.contrib.andrew.cmu.edu/ matthewm/ ALA_2001_chat.html. (Accessed 15 August 2004).

9. Josephine Z. Kibbee, David Henry Ward, and Wei Ma, "Virtual Service, Real Data: Results of a Pilot Study. Real-time Online Reference at the University of Illinois," Reference Services Review 30, no. 1 (2002): 25-36.

10. Diamond and Pease, "Digital Reference," 213-14.

11. Ibid., 217.

12. Powell and Bradigan, "E-mail Reference Services," 174.

13. Kibbee, Ward, and Ma, "Virtual Service, Real Data," 35.

14. Marsteller and Neuhaus, "The Chat Reference Experience at Carnegie Mellon University."

15. Bushallow-Wilbur, DeVinney, and Whitcomb, "Electronic Mail Reference Service."

16. Diamond and Pease, "Digital Reference."

17. Jerant and Firestein, "Not virtual, But a Real, Live, Online, Interactive Reference Service."

18. Ciccone and VanScoy, "Managing an Established Virtual Reference Service."

19. Marsteller and Mizzy, "Exploring the Synchronous Digital Reference Interaction for Query types, Question Negotiation, and Patron Response."

20. Parker and Johnson, "The Region 4 Collaborative Virtual Reference Project."

21. Powell and Bradigan, "E-mail Reference Services." sity."

22. Marsteller and Neuhaus, "The Chat Reference Experience at Carnegie Mellon Univer-

23. Kibbee, Ward, and Ma, "Virtual Service, Real Data."

24. Wendall Sullivan, Lisa A. Schoppmann, and Patricia M. Redman, "Analysis of the Use of Reference Services in an Academic Health Sciences Library," Medical Reference Services Quarterly 13 (spring 1994): 35-55.

25. Kibbee, Ward, and Ma, "Virtual Service, Real Data," 33.

26. B. Franklin and T. Plum, "Library Usage Patterns in the Electronic Information Environment," Information Research 9, no. 4 (2004). Available online at http://informationr.net/ir/9-4/paper187.html. (Accessed 15 September 2004). 


\section{Appendix Virtual Reference Coding System}

\section{What is the month the question was submitted?}

\section{Who was the user?}

- Faculty/staff

- Undergraduate student

- Graduate student

- Non-UIC

- Don't know

- Referral from other question point service

- Aborted interaction

\section{How was the question received/submitted?}

- Chat

- E-mail

4. What was the Library/Department answering question?

- LHS

- Daley

- Science

- Gov Docs

- Special Collections

- Other

5. What was the subject area of question? (Choose best fit.) (Classify question about owned material by subject of the material [do you have...].)

- Basic sciences: Biology/chemistry/engineering/math

- Health sciences: Allied health, medicine, nursing, pharmacy, psychiatry, public health, health question asked by a consumer

- Liberal arts: Arts/architecture, business, education, English composition, geography, history, humanities, psychology, social science, social work, sociology

- Government question

- Library (services, policies, etc.)

- Other

\section{What was the type of question asked (general category) ?}

- Directional questions: General questions regarding location of services, policies, collections (where are the books), and materials (where are the journals), hours, directions

- Ready reference (factual): Question that can be answered quickly (do you have this book, do you have this journal), simple fact look-up

- In-depth/mediated: Questions not easily answered (where can I find a copy of the Diagnostic Interview Schedule for Children, normal results of a liver enzyme test, how prevalent is TB in IL, relationship of crime to expansion of cities and suburbs, history of race in American political system)

- Instructional: Questions requiring some form of instruction to answer (How do I use $\mathrm{X}$ database, doing an article on $\mathrm{X}$ and need journal articles, how do I use e-mail)

- Technical: Difficulty accessing a resource, PDF problems, browsers problems, problem with net ID 
- Accounts, status: Status check on requested items, account probes (ILL, circulation, My Accounts)

\section{What was the type of question asked (specific)? Please choose the most appropriate based on what was the main focus of the question.}

- Looking for articles on X: How do I find articles on X, help with search strategy or suggest terms (strategy based)

- Research consultation: In-depth question where librarian creates search strategy and provides citations

- Where would I find information about X (this would be a more general request than 1)

- Database mechanics: How do I search/use this resource/navigate/instructional

- Accessing e-resources (location of database, do we have, identify a database to use)

- Accessing e-journals (do you have this e-journal, how do I get to this e-journal, why can't I access this journal from 1985 online)

- Do you have this book?

- Do you have this journal?

- Do you have this material (audio/visuals/sounds/slides/special collections (online or at UIC)?

- Factual question (discrete answers, nonstatistical, definitions) (how many CCs, how many colors in rainbow)

- Statistical information (how many people born in 1950)

- Technical problem/access issues (browser won't reload, Web page is missing, how do I get in from home, how do I get passwords or a net ID, is the server down)

- Info about library hours, location

- Questions about UICCAT, My Account

- Questions about circulation, ILL services \& policies (circ, ILL, Illinet, reserves)

- Citation verification

- Suggestions for collection

- Notice of errors (journals, Web pages)

- Complaints, courtesies (nonquestions)

- Question about Blackboard

- Other 
ASSOCIATION OF COLLEGE AND RESEARCH LIBRARIES

A Division of the American Library Association

\section{CALL FOR NOMINATIONS 2006 DIVISION AWARDS}

EXCELLENCE IN ACADEMIC LIBRARIES AWARD

$\$ 3,000$ and plaque

Sponsored by Blackwell's Book Services

\section{Hugh C. AtKinson Memorial AWARd}

Cash award and plaque

Sponsored by ACRL, ALCTS, LAMA, LITA

ACADEMIC OR RESEARCH LIBRARIAN OF THE YEAR

AWARD

$\$ 3,000$ and citation

Sponsored by YBP Library Services

\section{SAMUEL LAZEROW FELLOWSHIP}

$\$ 1,000$ and plaque

Sponsored by Thomson Scientific

\section{DOCTORAL DISSERTATION FELLOWSHIP}

$\$ 1,500$ and plaque

Sponsored by Thomson Scientific

SUBMIT NOMINATIONS FOR THE

2006 AWARDS PROGRAM BY DECEMBER 2 TO

Megan Bielefeld

ACRL Program Coordinator

50 East Huron Street, Chicago, IL 60611

Phone: (312) 280-2514

E-mail: mbielefeld@ala.org

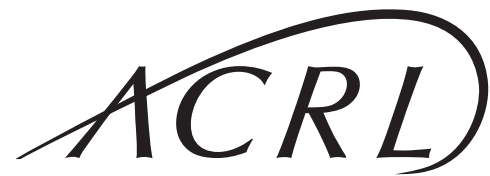

Association of College

\& Research Libraries

A Division of the American Library Association

MORE DETAILS IN THE AWARDS SECTION OF THE ACRL WEB SITE:

WWW.ala.org/acrl 